Mathematics and Educations Journal

Volume 1 Nomor 1, Juni 2019

\title{
EFEKTIFITAS METODE TRAPESIUM DAN SIMPSON DALAM PENENTUAN LUAS MENGGUNAKAN PEMROGRAMAN PASCAL
}

\author{
Nining Herfina ${ }^{1)}$, Amrullah ${ }^{2)}$, Junaidi ${ }^{3)}$ \\ ${ }^{1)}$ pendidikan matematika, FKIP, Universitas Mataram, Jln. Majapahit No. 62 Mataram, \\ niningherfina@gmail.com \\ ${ }^{2)}$ Pendidikan Matematika, FKIP, Universitas Mataram, Jln. Majapahit No. 62 Mataram, \\ Email: amrullah.mtk@gmail.com \\ ${ }^{3}$ Pendidikan Matematika, FKIP, Universitas Mataram, Jln. Majapahit No. 62 Mataram, \\ Email: junaidi88@unram.ac.id
}

\begin{abstract}
Abstrak. Suatu daerah ada yang berbentuk beraturan ada juga yang berbentuk tidak beraturan. Daerah yang beraturan mempunyai rumus baku untuk menentukan luasnya. Daerah yang tidak beraturan dapat dibatasi oleh suatu garis fungsi baik fungsi linear maupun fungsi non linear. Oleh karena itu penentuan luas daerah tersebut dapat diperoleh menggunakan metode integrasi. Metode integrasi yang dikenal diantaranya adalah metode trapesium dan metode Simpson. Penelitian ini bertujuan untuk menentukan efektifitas metode trapesium dan metode Simpson menggunakan bahasa pemrograman Pascal. Jenis penelitian yang digunakan adalah jenis eksperimen. Pada penelitian ini diperoleh hasil bahwa (a) Metode trapesium dan metode Simpson dapat diimplementasikan pada bahasa pemrograman Pascal sehingga diperoleh software penentuan luas daerah poligon dengan hasil yang sama dengan nilai eksak dan (b) Metode trapesium dan metode Simpson sama-sama efektif dalam penentuan luas daerah berbentuk poligon. Perhitungan menggunakan bahasa pemrograman Pascal antara metode trapesium dan metode Simpson menunjukkkan bahwa hasil luas daerah berbentuk poligon sama dengan nilai eksaknya (tidak ada galat) serta dalam mengeksekusi algoritma pada pemrograman pascal tersebut menunjukkan waktu eksekusi yang sama.
\end{abstract}

Kata kunci: efektifitas; metode trapesium; metode Simpson; Pascal.

\begin{abstract}
An area might have regular or irregular shape. The regular area already has a standard formula to determine the size while the irregular area can be boundred by a function line whether it is a linear function or non-linear function. Therefore, the area determination can be obtained by using the integral method. The integration method which is known etc Trapezoid and Simpson methods. This study aims to determine the effectiveness of the trapezoid and Simpson methods using pascal programming language. The type of program used is the experiment one. The result of this study found that (a) trapezoid and Simpson methods can be implemented in Pascal programming language so that the software of a polygon area is obtained with the same result as the exact value and (b) the trapezoid and Simpson methods are equally effective in determining an area in polygon shape. The calculation using Pascal programming language between trapezoid and Simpson methods shows that the result of an area in polygon shape is the same with the exact value (no error) and in executing the algorithm in the Pascal program shows the same execution time.
\end{abstract}

Keyword: effectiveness; trapezoid method;simpson method; pascal 


\section{PENDAHULUAN}

Dalam bidang sains dan rekayasabanyak ditemukan penggunaan metode trapesium dan metode Simpson, Oleh karena itu, banyak peneliti menerapkan kedua metode integrasi tersebut untuk menyelesaikan masalah dalam kehidupan seharihari.Namun,masing-masing penelitian yang dilakukan terdahulu membandingkan dua metode hanya ditinjau dari galat atau hasil errornya saja. Dalam pembelajaran matematika yang dibahas tidak hanya yang berkaitan dengan fungsi polinom saja tetapi juga ada yang lain yang yaitu yang berkaitan dengan poligon. Seperti yang diketahui bahwa biasanya yang dipelajari hanya membahas atau mempelajari tentang bagaimana cara menyelesaikan masalah-masalah yang berkaitan dengan menentukan luas suatu daerah yang berada di bawah kurva, sedangkan dalam matematika tidak hanya di bahas tentang fungsi polinom-polinom saja melainkan ada juga tentang poligon yang harus dikaji.Oleh karena itu, pada penelitian ini akancari metode yang efektif dalam penentuan luas daerah poligon yang akan diperhatikan tidak hanya error atau galatnya saja tetapi kecepatan algoritma serta waktu penyelesaian masalah. Hampir semua penelitian di atas menggunakan pemrograman matlab. Pada penelitian ini akan menggunakan pemrograman pascal.

Suatu daerah ada yang berbentuk beraturan ada juga yang berbentuk tidak beraturan. Suatu daerah yang beraturan antara lain suatu daerah yang berbentuk persegi panjang, segitiga, lingkaran, trapesium dan lainnya, semua daerah yang beraturan sudah mempunyai rumus baku untuk menentukan luasnya. Untuk daerah yang tidak beraturan, ada yang dibatasi sebuah fungsi dimana fungsi itu sudah diketahui, maka untuk menentukan luas daerah yang tidak beraturan dan fungsinya diketahui menggunakan integral biasa, tetapi daerah yang tidak beraturan dan fungsi tidak diketahui untuk menentukan luas daerahnya harus menggunakan integrasi numeric [1].

Metode trapesium termasuk metode Newton Cotes orde pertama. Dalam metode ini grafik fungsi $y=f(x)$ didekati dengan garis lurus yang menghubungkan titik $(a, f(a))$ dan $(b, f(b)$. Dengan demikian luas daerah dibatasi oleh kurva $y=f(x)$. Garis $x=a$ dan garis $x=b$ dihampiri oleh trapesium yang 
dibatasi oleh garis lurus yang menghubungkan titik $(a, f(a))$ dan $(b, f(b))$, garis $x=a$, dan garis $x=b$ dan sumbu $-x$. Dengan menggunakan rumus luas untuk trapesium segmen tunggal berikut ini.

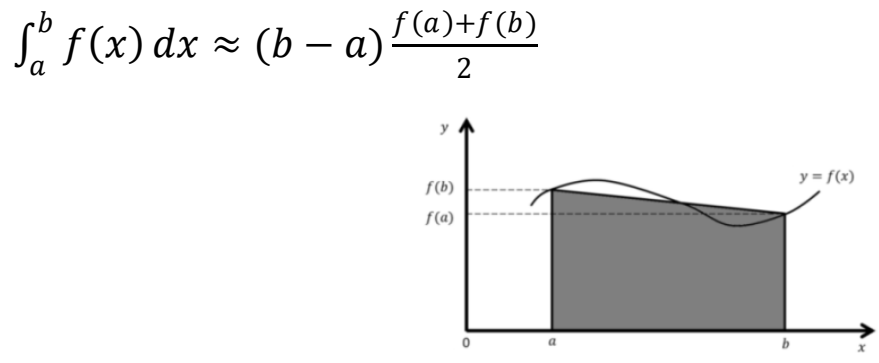

\section{Gambar 1.1 Metode Trapesium Segmen Tunggal}

Untuk mengurangi besarnya kesalahan yang terjadi, dapat digunakan sederetan (beberapa) garis lurus untuk mendekati kurva lengkung secara sepotong-sepotong sehinga terbentuk beberapa daerah trapesium.Cara ini disebut metode trapesium segmen ganda.

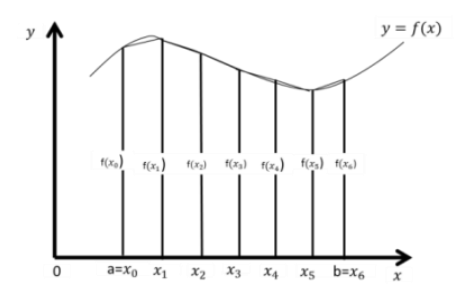

\section{Gambar 1.2 Metode Trapesium Segmen Ganda}

. Dengan menjumlahkan $n$ buah luas bertanda dari trapesium-trapesium tersebut, didekati integralnya

$$
\int_{a}^{b} f(x) d x \approx \frac{h}{2}\left(f\left(x_{0}\right)+f\left(x_{n}\right)+2 \sum_{i=1}^{n-1} f\left(x_{i}\right)\right)
$$

Algoritma dari metode trapesium yaitu:

1. Mendefinisikan fungsi $f(x)$ yang akan diintegrasi

2. Menentukan batas bawah $(a)$ dan batas atas $(b)$ integrasi

3. Menentukanjumlah segmen $(n)$

4. Menghitunglebar segmen yaitu $h=\frac{b-a}{n}$

5. Melakukanperhitungan dengan diketahui $i=1,2,3, \ldots, n-1$,

$$
x_{i}=a+i * h
$$


Mathematics and Educations Journal

Volume 1 Nomor 1, Juni 2019

6. Masukkan $x_{i}$ pada $f(x), f(x)=f\left(x_{i}\right)$

7. Menghitung jumlahnya dengan menggunakan persamaan

$$
\int_{a}^{b} f(x) d x \approx \frac{h}{2}\left(f\left(x_{a}\right)+f\left(x_{b}\right)+2 \sum_{i=1}^{n-1} f\left(x_{i}\right)\right)
$$

Aturan Simpson 1/3 adalah metode newton cotes orde dua karena menggunakan polinom orde dua untuk mendekati $f(x)$.

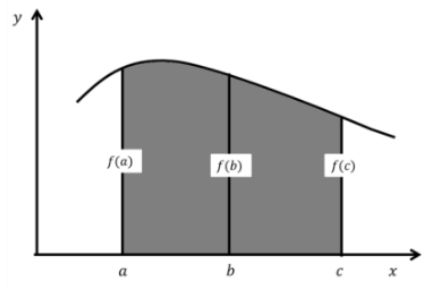

Gambar 1.3 Aturan Simpson 1/3 Segmen Tunggal

Rumus aturan Simpson 1/3 yaitu

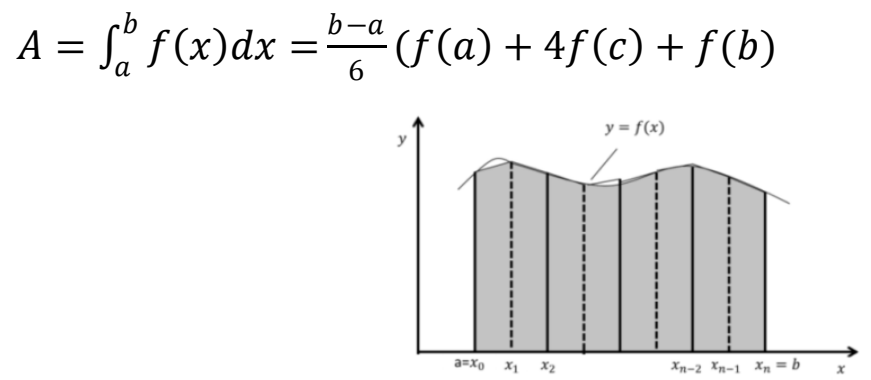

\section{Gambar 1.4 Aturan Simpson 1/3 Dengan $n$ Daerah (Segmen Ganda)}

Jika digunakan aturan Simpson 1/3 dengan $n$ daerah, maka interval $[a, b]$ harus dibagi menjadi $n$ sub interval yang sama panjang dengan $h=\frac{b-a}{n}$ dan $n$ harus genap. Sehingga luas total diperoleh dengan menjumlahkan semua luas daerah bagiannya.

Dapat dituliskan dalam bentuk

$\int_{a}^{b} f(x) d x \approx \frac{\Delta x}{3}\left(f_{0}+4 f_{1}+2 f_{2}+4 f_{3}+2 f_{4}\right)+\ldots+2 f_{n-2}+4 f_{n-1}+f_{n}$

Dengan pola koefisien adalah $1,4,2,4,2, \ldots, 4,2,4,1$.Dimana $f^{(4)}$ adalah rerata turunan keempat untuk setiap interval.

Pada penelitian ini menggunakan aturan Simpson 1/3 sehingga rumus yang digunakan pada algoritma ini adalah rumus dari aturan Simpson 1/3, berikut algoritmanya. 
1. Mendefinisikan fungsi $f(x)$ yang akan diintegrasi

2. Menentukan batas bawah $(a)$ dan batas atas $(b)$ integrasi

3. Mentukanjumlah segmen $(n)$

4. Menghitunglebar segmen yaitu $h=\frac{b-a}{n}$

5. Melakukanperhitungan diketahui $i=1,2,3, \ldots, n-1$,

$$
x_{i}=a+i * h
$$

6. Memasukkan $x_{i}$ pada $f(x), f(x)=f\left(x_{i}\right)$

7. Menghitung jumlahnya dengan menggunakan persamaan

$$
\int_{a}^{b} f(x) d x \approx \frac{1}{3} h\left[f\left(x_{a}\right)+f\left(x_{b}\right)+4 \sum_{i=\text { ganjil }}^{n-1} f\left(x_{i}\right)+2 \sum_{i=\text { genap }}^{n-2} f\left(x_{i}\right)\right]
$$

$[2]$.

Dalam hasil numerik tentu terdapat suatu galat. Galat adalah selisih antara nilai eksak dan nilai absolute [3]. Menurut [4] galat (error) berasosiasi dengan seberapa dekat solusi hampiran terhadap solusi sejatinya (eksak).

\section{METODE PENELITIAN}

\section{a. Jenis Penelitian}

Penelitian ini merupakan penelitian jenis eksperimen.

\section{b. Algoritma Penelitian}

Adapun algoritma yang digunakan dalam menentukan luas daerah poligon yang tidak beraturan pada penelitian ini adalah sebagai berikut.

1. Penentuan $n$ untuk poligon segi $n$

2. Penentuan $x_{i}$ dan $y_{i}$ untuk n titik, dimana $i=1,2,3, \ldots, n$

3. Hitung persamaan garis lurus antara $x_{i}, y_{i}$ dan $x_{i+1}, y_{i+1}$, dimana

$$
i=1,2,3, \ldots, n-1
$$

4. Tentukan persamaan setiap ruas garis

5. Tentukan batas bawah dan batas atas (interval) setiap persamaan 
Mathematics and Educations Journal

Volume 1 Nomor 1, Juni 2019

6. Tentukan fungsi atas dan fungsi bawah

7. Hitung luasan menggunakan algoritma metode trapesiun atau menggunakan algoritma metode Simpson

$$
\begin{aligned}
& A_{1}=\int_{a}^{b} f_{1} \\
& A_{2}=\int_{a}^{b} f_{2} \\
& L=A_{1}-A_{2}
\end{aligned}
$$

Diulang sampai $n-1$

\section{c. Prosedur Penelitian}

Langkah-langkah yang akan dilakukan dalam penelitian ini adalah sebagai berikut.

1. Persiapan

2. Implementasi Metode Menggunakan Pascal

3. Uji Program

4. Revisi Program

5. Analisis

6. Kesimpulan

\section{HASIL DAN PEMBAHASAN}

\section{A. Hasil Penelitian}

Source code yang dibuat sudah sesuai dengan algoritma pada metode trapesium dan metode Simpson, maka dilakukan uji coba dengan menggunakan

\begin{tabular}{|c|c|c|c|c|c|}
\hline \multirow[t]{2}{*}{ Fungsi } & \multirow[t]{2}{*}{ Eksak } & \multicolumn{2}{|c|}{ Trapesium } & \multicolumn{2}{|c|}{ Simpson } \\
\hline & & Hasil & Galat & Hasil & Galat \\
\hline 1. $\int_{0}^{5} 2 x+5 d x$ & 50 & 50 & 0 & 50 & 0 \\
\hline 2. $\int_{0}^{5} 3 x^{2}+4 x+1 d x$ & 180 & 183,91 & 0,02 & 180 & 0 \\
\hline
\end{tabular}
fungsi linear dan fungsi non linear menggunakan pemrograman pascalberikut.

Tabel 3.1 Uji Coba Program 


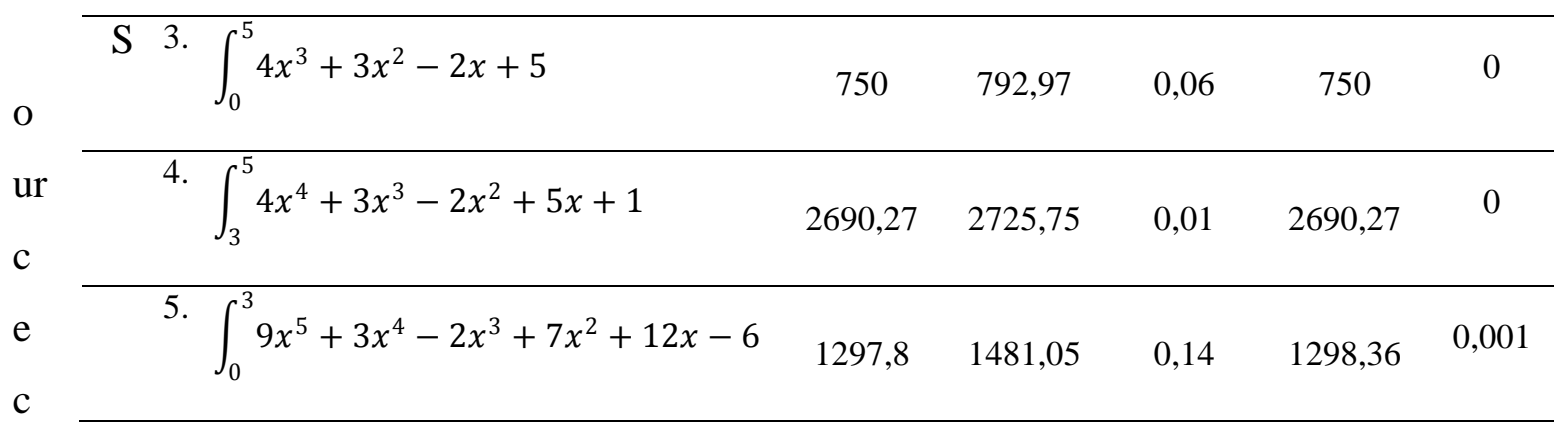

ode yang ditulis pada program metode trapesium maupun program metode Simpsonakan menampilkan output berupa perintah untuk memasukkan jumlah titik pada poligon yang akan dihitung, sehingga dalam menentukan luas poligon dengan menggunakan program Pascal ini hanya perlu memasukkan nilai dari pasangan setiap titik dari poligon tersebut. Selanjutnya user hanya perlu menekan tombol enter pada keyboard komputernya maka akan keluar output berupa persamaan dari setiap ruas garis poligon, luas di bawah kurva dari setiap fungsi, luas poligon, waktu yang dibutuhkan untuk menjalankan program, serta gambar poligon sesuai titik yang diinput.

Uji program dilakukan dengan membandingkan hasil running program pada beberapa poligon dengan jumlah titik yang berbeda.Hal tersebut dilakukan untuk mengetahui apakah jumlah titik mempengaruhi waktu eksekusi program yang dibutuhkan atau tidak. Pada poligon tersebut akan digunakan banyak partisi $(n)$ yang berbeda serta harus genap. Satuan waktu yang digunakan pada program ini adalah (mili detik).

Tabel 3.2 Uji Program

\begin{tabular}{ccccccc}
\hline \multirow{2}{*}{ No. } & \multirow{2}{*}{ Banyak titik } & \multirow{2}{*}{ Eksak } & \multicolumn{2}{c}{ Trapesium } & \multicolumn{2}{c}{ Simpson } \\
\cline { 5 - 7 } & & & Hasil & Waktu & Hasil & Waktu \\
\hline 1. & 5 & 440000 & 440000 & 15 & 440000 & 16 \\
\hline 2. & 6 & 335000 & 335000 & 32 & 335000 & 31 \\
\hline 3. & 7 & 170000 & 170000 & 31 & 170000 & 32 \\
\hline 4. & 8 & 265000 & 265000 & 46 & 265000 & 46 \\
\hline 5. & 9 & 625000 & 625000 & 47 & 625000 & 46 \\
\hline 6. & 10 & 1045000 & 1045000 & 63 & 1045000 & 62 \\
\hline 7. & 11 & 675000 & 675000 & 62 & 675000 & 63 \\
\hline 8. & 12 & 715000 & 715000 & 63 & 715000 & 62 \\
\hline 9. & 14 & 685000 & 685000 & 79 & 685000 & 79 \\
\hline 10. & 17 & 1000000 & 1000000 & 110 & 1000000 & 109 \\
\hline
\end{tabular}




\section{B. PEMBAHASAN}

Penyelesaian integral pada Tabel 3.1 sesuai dengan algoritma metode trapesium dan metode Simpson yang diimplementasikan ke dalam pemrograman Pascal. Uji coba dalam menyelesaikan fungsi linear dan fungsi non linear tersebut digunakan banyaknya partisi $(n)$ adalah 4. Berdasarkan Tabel 3.1 pada fungsi yang pertama yaitu fungsi linear didapatkan hasil antara metode trapesium dan metode Simpson memperoleh hasil yang sama dengan nilai eksaknya, artinya tidak ada galat yang ditimbulkan jika suatu fungsi linear diselesaikan dengan kedua metode tersebut. Subarina (2013:107) mengatakan bahwa dalam metode trapesium, grafik fungsi $y=f(x)$ didekati dengan garis lurus yang menghubungkan titik $(a, f(a)) \operatorname{dan}(b, f(b)$. Dengan demikian luas daerah dibatasi oleh kurva $y=f(x)$. Garis $x=a$ dan garis $x=b$ dihampiri oleh trapesium yang dibatasi oleh garis lurus yang menghubungkan titik $(a, f(a))$ dan $(b, f(b))$, garis $x=a$, dan garis $x=b$ dan sumbu $-x$. Pada penelitian ini fungsi $y=f(x)$ merupakan fungsi linear (garis lurus), sehingga dengan menggunakan metode trapesium untuk mendekati daerah yang sebenarnya tentu saja mengakibatkan tidak adanya galat (kesalahan). Bahkan tanpa menggunakan banyak partisi selangpun untuk mendekati kurva garis lurus tersebut tetap saja tidak menghasilkan galat, sebab ketika kurva garis lurus ditentukan luasnya menggunakan garis lurus maka tidak menimbulkan galat. Hal ini senada dengan metode Simpson yang memberikan hasil yang sama dengan nilai eksaknya. Metode Simpson menggunakan orde lebih tinggi dibandingkan dengan metode trapesium.Sejalan dengan pendapat [2] yang mengatakan bahwa fungsi yang biasanya digunakan untuk mendekati fungsi integral atau data fungsi adalah polinom orde tertentu. Secara umum, semakin besar orde polinom yang digunakan untuk mendekati, maka akan semakin kecil galat yang ditimbulkan sehingga hasilnyapun lebih akurat. Sejalan dengan penelitian yang dilakukan oleh [5] bahwa fungsi aljabar yang sangat sederhana dan berupa garis lurus menghasilkan nilai yang sama dengan nilai eksaknya jika fungsi tersebut diselesaikan dengan metode numerik yaitu menggunakan metode Romberg. 
Penyelesaian fungsi non linear menggunakan metode trapesium dan metode Simpson tersebut sama-sama dipartisi menjadi 4 selang. kemudian hasil yang didapatkan dari kedua metode tersebut akan dibandingkan dari segi galatnya. Pada Tabel 3.1 terlihat dari semua contoh fungsi yang non linear menunjukkan bahwa galat metode trapesium lebih besar dibandingkan dengan metode Simpson. Ini berarti metode Simpson memberikan hasil yang lebih teliti untuk menyelesaikan fungsi non linear. Hal tersebut disebabkan karena fungsi non linear secara geometri akan membentuk kurva lengkung sehingga ketika kurva lengkung tersebut didekati dengan metode Simpson yang merupakan pendekatan dengan beberapa polinom maka hasilnya pun akan mendekati hasil eksaknya. Hal ini memberikan kesimpulan bahwa metode Simpson memberikan galat yang lebih teliti dibandingkan dengan metode trapesium jika fungsi yang diselesaikan adalah fungsi non linear.

Berdasarkan hasil percobaan yang dilakukan pada beberapa contoh poligon tidak beraturan tersebut, maka didapatkan hasil seperti yang tertera pada Tabel 3.2. Penyelesaian dengan metode trapesium tersebut sama-sama mempartisi selangnya dengan jumlah yang berbeda-beda, akan tetapi seperti yang terlihat pada Tabel 3.2 bahwa antara metode trapesium maupun metode Simpson menghasilkan suatu perhitungan yang sama dengan nilai eksaknya, artinya tidak terdapat galat.

Pada penelitian ini, objek yang dicari luasnya adalah poligon. Poligon adalah sudut banyak suatu bidang oleh sejumlah penggal garis yang dibatasi oleh tiga atau lebih sisi yang saling bertemu pada titik sudut yang sama,serta penggal-penggal garis tersebut tidak saling berpotongan selain pada titik tersebut. Metode Trapesium dan metode Simpson ini adalah suatu metode yang digunakan untuk menghitung luas suatufungsi yang berada di bawah kurva.Pada penelitian ini kurva yang ditentukan luasnya berupa kurva linear karena objeknya berupa daerah berbentuk poligon. Daerah poligon tersusun atas beberapa garis lurus, sehingga fungsi yang ditentukan luasnya berupa garis lurus. Ketika fungsi linear tersebut didekati dengan metode trapesium maka hasil yang didapatkan sama seperti hasil eksaknya seperti yang ditunjukkan pada hasil uji coba Tabel 3.1 pada fungsi linear yang tidak menghasilkan galat baik metode tapesium maupun metode Simpson. Dengan kata 
lain bahwa galat yang diperoleh adalah nol dalam uji coba pada beberapa poligon tersebut. Hal ini senada dengan metode Simpson yang memberikan hasil yang sama dengan nilai eksaknya. Metode Simpson menggunakan orde lebih tinggi dibandingkan dengan metode trapesium.Berapapun jumlah partisi yang digunakan dalam percobaan menentukan luas poligon tersebut, hasilnya tetap sama seperti hasil eksaknya.

Waktu eksekusi program (Running time) pada metode trapesium maupun metode Simpson tersebut memiliki hasil yang hampir sama, jika ada perbedaan hanya berselisih 1 milidetik saja dari setiap percobaan yang dilakukan. Hal ini dikarenakan algoritma pada metode trapesium dan metode Simpson hampir mirip, yaitu pada rumusnya saja.Selisih waktu dari kedua metode tersebut tidaklah besar, bahkan relatif sama. Ini disebabkan karena fungsi yang dieksekusi bukanlah fungsi yang rumit melainkan fungsi linear.[6] menyatakan bahwa kebutuhan waktu suatu algoritma biasanya dihitung dalam satuan detik, mikrodetik, dan sebagainya, sedangkan memori yang digunakan dapat dihitung dalam satuan byte atau kilobyte. Biasanya orang mengukur kebutuhan waktu sebuah algoritma dengan mengeksekusi langsung algoritma tersebut pada sebuah komputer, lalu dihitung berapa lama durasi waktu yang dibutuhkan untuk menyelesaikan sebuah persoalan dengan $n$ yang berbeda-beda. Keakuratan waktu eksekusi algoritma dapat diperoleh dengan tidak menghitung kebutuhan waktu untuk menampilkan antarmuka program, operasi masukan/keluaran (baca,tulis), dan sebagainya. Jadi, benar-benar yang dihitung adalah kebutuhan waktu untuk bagian algoritma yang inti saja.

Pada penelitian ini algoritma yang dihitung kebutuhan waktunya adalah algoritma yang intinya saja, yaitu pada perhitungan dalam penentuan luas poligon dengan metode trapesium maupun dengan metode Simpson. Durasi waktu yang dibutuhkan untuk menentukan luas beberapa contoh poligon tersebut tidaklah terlalu berbeda, bahkan ada yang sama. Perbedaan waktu untuk mengeksekusi kedua metode tersebut hanya berselisih 1 milidetik. Pengujian untuk mengetahui keakuratan waktu dilakukan dengan berbagai macam bentuk poligon dengan jumlah $n$ yang berbeda-beda. Berdasarkan hasil pengujian yang didapatkan, bahwa ada pengaruh kebutuhan waktu eksekusi berdasarkan banyaknya jumlah titik dari 
setiap poligon tersebut. Terlihat pada Tabel 3.2 yang menunjukkan bahwa semakin banyak jumlah titik poligonnya maka semakin besar waktu yang dibutuhkan untuk mengeksekusi algoritma tersebut. Hal ini dikarenakan bahwa semakin banyak titik yang diinput, maka akan semakin banyak jumlah langkah yang dilakukan dan semakin banyak pula waktu yang dibutuhkan.

\section{KESIMPULAN}

Berdasarkan hasil dan pembahasan yang diperoleh, maka dapat disimpulkan bahwa: Metode trapesium dan metode Simpson dapat diimplementasikan pada bahasa pemrograman Pascal sehingga diperoleh software penentuan luas daerah poligon dengan hasil yang sama dengan nilai eksak. Metode trapesium dan metode Simpson sama-sama efektif dalam penentuan luas daerah berbentuk poligon. Perhitungan menggunakan bahasa pemrograman Pascal antara metode trapesium dan metode Simpson menunjukkkan bahwa hasil luas daerah berbentuk poligon sama dengan nilai eksaknya (tidak ada galat) serta dalam mengeksekusi algoritma pada pemrograman pascal tersebut menunjukkan waktu eksekusi yang sama.

\section{DAFTAR PUSTAKA}

[1] Nurhadiyono, Bowo dan Rahayu, Yuniarsi. (2012). Penerapan Integrasi Numerik Menggunakan Metode Segiempat (Rectangle Rule) Untuk Menghitung Luas Daerah Beraturan.Jurnal Tecno.COM Vol. 11. No. 4: 181-193.

[2] Subarinah, Sri. (2013). Metode Numerik. Mataram: FKIP Prees Universitas Mataram.

[3] Underwood, A.L dan Day, R.A. (2002). Analisis Kimia Kuantitatif. Jakarta: Erlangga.

[4] Prasetya, Adi. (2016). Performansi Metode Trapesium dan Gauss LegendreDalam Penyelesaian Integral Tertentu Berbantuan Matlab. Jurnal Mercumatika. Vol. 1. No. 1: 2.

[5] Munir, Rinaldi. (2010). Matematika Dikstrit. Bandung: Informatika.

[6] Rahayu, Puji. Perbandingan Solusi Numerik Metode Romberg dan Simulasi Monte Carlo Pada Penyelesaian Integral. Skripsi UIN Alauddin: Makassar. 